大規模津波災害に対応した地域 住宅再建推進体制づくりに関す る考察

\section{一岩手県陸前高田市の住宅再建推進活 動を通じてー}

CONSIDERATION ON LOCAL HOUSING RECONSTRUCTION SYSTEM FOR LARGE-SCALE TSUNAMI DISASTER

- Through the action of housing reconstruction in Rikuzentakata city -
鈴木大隆— $* 1$ 石井 旭 - $* 2$

キーワード :

東日本大震災，陸前高田，住宅再建，地域生産，被災住民

Keywords:

Great East Japan Earthquake, Rikuzentakata-city, Housing reconstruction, Local construction system, Disaster victims
Hirotaka SUZUKI —— $* 1 \quad$ Akira ISHII-_ $* 2$

The purpose of this paper is to examine a house reconstruction system by local builders from a large-scale tsunami disaster. Through the activity of the house reconstruction in Rikuzentakata-city, following knowledges were provided: (1) In early stage of reconstruction, it is efficient to set up a system in a logistical support place. (2) For the development stage, it is better to organize by resident's association with expert support in order to sustain the community. (3) In spread period, it is effective to organize by the construction industry association in order to deal with specialized issues.

\section{1.はじめに}

住宅再建は自然災害からの生活再建において必須のプロセスであ る。その方法は「自力住宅再建」に代表される民間主体のもの、災害 公営住宅や防災集団移転促進事業（以下、「防集事業」）等に代表され る公共主体のものがあり、それらは同時に進行する。

東日本大震災のように人口減少著しい地方都市で激甚災害が発生 した場合、地域に存在する建設事業者はがれき処理や軽微な損傷を 受けた住宅建築物の修繥・改修、木造応急仮設住宅の建設など、域外 の大規模事業者が即応し難い様々な復旧業務を担う。建設事業者の 殆どは中小企業体注1)であるため、多くの業務を担うには限界がある。 地域の住宅事業者が “住宅再建”にどの時点から関わるかについて は、被災程度や復旧初期に担う業務、そして災害公営住宅かそれ以外 の民間主導の住宅再建を担うかで異なる。しかしいずれの場合でも、 地場の住宅事業者による住宅再建は、その地域特有の気候風土に根 差した暮らしや技術の再生、長く暮らし続けるなかで必要不可欠な 維持管理の継続性、地域の産業の継承と持続の面から意義があり、 復興後の持続的なまちづくりにおいて重要な要素と言える。

東日本大震災では、大量の住宅再建に対応するため、被災三県の地 場の住宅事業者が中心となった「地域型復興住宅推進協議会」例えば 4 ８）傘下の住宅生産者グループ、木造災害公営住宅建設のための住宅 生産者グループ例えば9) など、様々な取り組みが行われてきた例えば10)

筆者らは、発災直後から岩手県気仙地区 (大船渡市、陸前高田市、 住田町）、その後、陸前高田市の住宅再建活動にかかわってきたが、 活動初期から、これまでの災害の住宅再建とは異なる対応が必要と なると予想していた。例えば図 1 は、過去の災害の住宅建設の累積 比率と 2014 年 3 月時点の東日本大震災における陸前高田市の住宅供

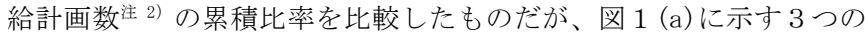
災害ではいずれも $2 \sim 3$ 年後には半数の住宅再建が進み、 5 年後には 概称完了している。一方、図 1(b) に示寸ように陸前高田市では住宅 再建が長期に渡るほか、発災から 5 年後（2016 年）と8 年後 (2019 年) に住宅供給のピークがくると予想された。これらは高台移転等に 伴う用地取得や大規模造成に時間を要することが要因として挙げら れるが、長期化する住宅再建と経年により変化するであるう住要求 や、復興後期に生じる最大ピークに対応し得る柔軟な体制づくりが 必要になることを意味する。

本報は、これらを踏まえ取り組んだ岩手県気仙地区及び陸前高田 市を対象とした住宅再建支援活動とその一環で行った住宅再建に関 する各種調查等から得た実践的知見等を報告するとともに、今後の 大規模津波災害に対応寸る住宅再建推進体制づくりについて提案す ることを主な目的とする。
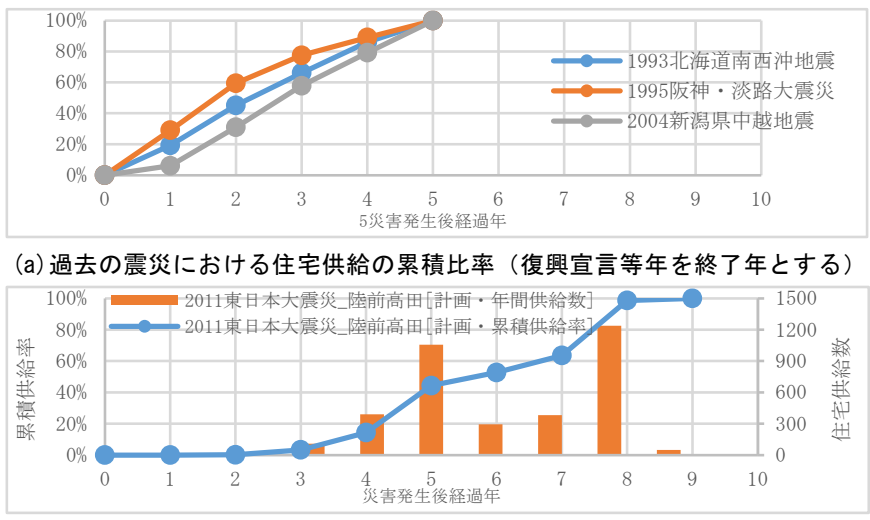

（b）東日本大震災における陸前高田市の住宅供給計画数の累積比率（2014. 3 時点） 図 1 過去の震災と東日本大震災における陸前高田市の住宅供給の比較

\footnotetext{
（地独）北海道立総合研究機構 理事・博士（工学）

（广 060-0819 北海道札幌市北区北 19 条西 11 丁目)

(地独) 北海道立総合研究機構建築研究本部北方建築総合研究所

主査・修士（工学）
}

\footnotetext{
Vice President, Hokkaido Research Organization, Dr. Eng.

Chief Researcher, Hokkaido Research Organization, Building Research Dept., Northern Regional Building Research Inst., M. Eng.
} 


\section{2. 住宅再建支援活動の概要}

以下では、発災直後から関わってきた気仙地区を対象とした「広域 的支援活動」、陸前高田市を対象とした「住民主体の活動」と「住民 と地場事業者等による総合的支援活動」に関して時系列に概説し（図 2)、その活動から得られた実践的知見について述べる。

(1)気仙地区を対象とした広域的支援活動【図 2 (a)】

図 3 は、大船渡市・陸前高田市の 2014 年 3 月時点での住宅供給予 測を示している注 5) が、両市合わせた年間再建数が 2013 年に 500 戸 を超え、2019 年には計 900 戸となり陸前高田市で最大となると予想 される。一方、発災前の 2010 年時点における年間新築住宅建設戸数 注 6) によれば、気仙二市一町合わせての住宅生産能力は 178 戸であり、 その差は大きい。需要の全てを地場で担うことは難しいものの、前述 の通り、地場で住宅再建を担う意義は大きいことから大量需要のう ちの一定数を担うべく、以下の特徴を有する体制づくりを進めた。

- 岩手県地域型復興住宅推進協議会の傘下に県内 135、気仙地域 10 に設置された住宅建設を目的とする住宅生産者グループとは異な り、地場の建設業協会及び加盟社、関係団体と行政等から構成され る住宅再建を支援する広域連携的体制を目指す。

•大船渡市(津波による全壊住宅 2, 791 棟注7) と陸前高田市(同 3,807 棟注 7) ) で今後予想される住宅供給数、時期の違いをふまえ、両市 の住宅需要の平準化と生産力の共有化を図る。

- 沿岸被災地の事業者が各種相談業務を担う人的資源や時間を確保 できない状況を鑑み、これらの公益的支援業務や運営マネジメント の拠点は直接的被害が少ない内陸の住田町に形成する。 なお、これらの活動は、2011 年 12 月に内閣府が指定した「気仙広
域環境未来都市構想（大船渡市・陸前高田市、住田町等で構成）」の 一つに掲げられた「地域木造復興住宅プロジェクト」を国土交通省と 連携し実施したものである。復興モデル住宅のコンセプトは概ね以 下の通りである。

三陸沿岸部の基幹産業は水産業だが、就業者率でみると他の地方 都市と同様に二次・三次産業の従事者が多く、市街地は地方都市 と変わらない都市型住宅が中心である。一方で、集落等に多く居住す る一次産業従事世帯は “半農半 X” をなりわいとし、大きな敷地に 40 坪超の木造平屋等の大規模住宅と農作や自家消費用の畑・作業場な どを備えた住宅が多く存在していた（図 4)。公共が行う宅地造成の うち主に集落部で適用された防集事業では、約 100 坪という限られ た敷地面積で発災後の暮らしがどう変化し、どう住宅再建す心゙きか のイメージがつかめない被災世帯が殆どであった。そのため、100 坪 の敷地で自家農園や駐車スペース等も含めた敷地内の空間利用方法 と住宅規模・隣棟間隔、断熱・省エネ等の最新技術の見える化など、 見学体験の場をつくることを目的として、住田町内に復興モデル住 宅を建設した（図 5)。住宅は、主として集落での建設を想定した平 屋 (A) と一部 2 階建住宅 (B)、市街地での建設も想定した総 2 階建住 宅 (C)の 3 タイプとした。なお、国土交通省地域住宅グリーン化事業 を活用した長期優良住宅を適用し、建設時の技術講習や現場指導、現 場検査・監理などを通じて、これまで長期優良住宅の経験がなかった 地場事業者の技術力向上にも取り組んだ。

2013 年 4 月に着工し、2013 年 7 月に現場見学会、同年 10 月から 一定期間にわたり完成見学会を行った。気仙地区から延べ 500 世帯 以上が来場し、終了後は個人に売却された。来場者へのアンケート結

2012 年 4 月から

2012 年 10 月から

2014 年 4 月から

\begin{tabular}{|c|c|c|}
\hline ·大船渡市 $\frac{\text { 【市町村】 }}{\text { ·陸前高田市 }}$. 住田町 & & • 陸前高田市（事業費補助） \\
\hline $\begin{array}{ll}\text { ·道総研 } \\
\text { ·設計事務所 }\end{array}$ & 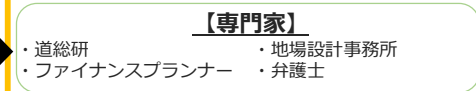 & 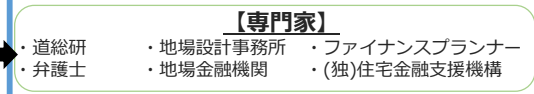 \\
\hline ·気仙管内住宅生産者 & ·気仙管内住宅生産者(有志) & $\begin{array}{l}\text { 【住宅事業者】 } \\
\text { 陸前高田市建設業協会会員社 }(H 26.4 \text { 時点市内39社) }\end{array}$ \\
\hline & 【仮設自治会・防災集団移転協議会】 & ·建材·住宅設備メーカ一 $\frac{\text { 【協力組織】 }}{\text { 商社等 }}$ \\
\hline ·共同事業体事務局 & 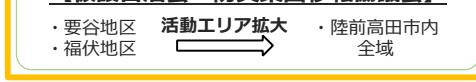 & 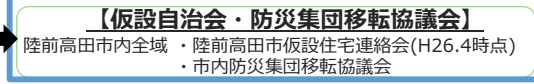 \\
\hline $\begin{aligned} \text { 【主な事業】・モデル住宅建設 } \\
$\[ \cdot \text { 住宅生産体制の検討 } \]$\end{aligned}$ & $\begin{aligned} \text { 【主な事業】・説明会・相談会 } & \text { ・モデル住宅建設 } \\
& \text { ·住民意向把握 }\end{aligned}$ & $\begin{aligned} \text { 【主な事業】・説明会・相談会 } ・ \text { 住民二ーズ調査 } \\
$\[ \cdot \text { 住民再建への導 ・住宅生産システム検討 } \]$\end{aligned}$ \\
\hline
\end{tabular}

実施主体：気仙広域環境未来都市推進事業体 陸前高田 住まいの再建を考える会 （一社）陸前高田市建設業協会住宅再建推進協議会 (a) 気仙地区を対象とした広域的活動

(b) 住民主体の活動

（c）住民と地場事業者等が中心となった総合的活動

\section{図 2 住宅再建の取組み体制の変遷}

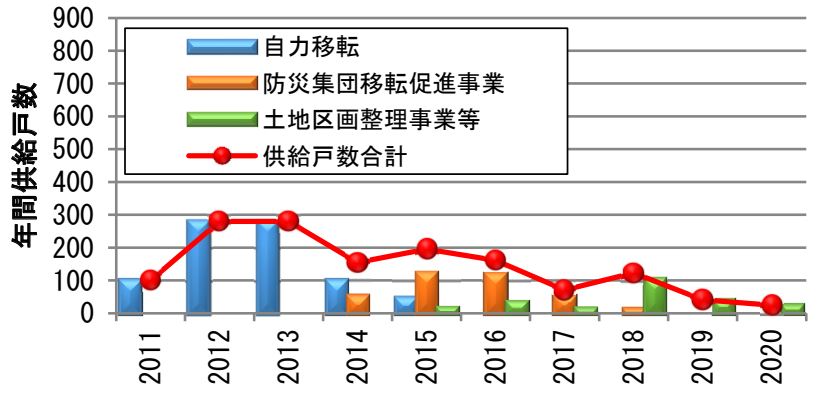

(a) 大船渡市

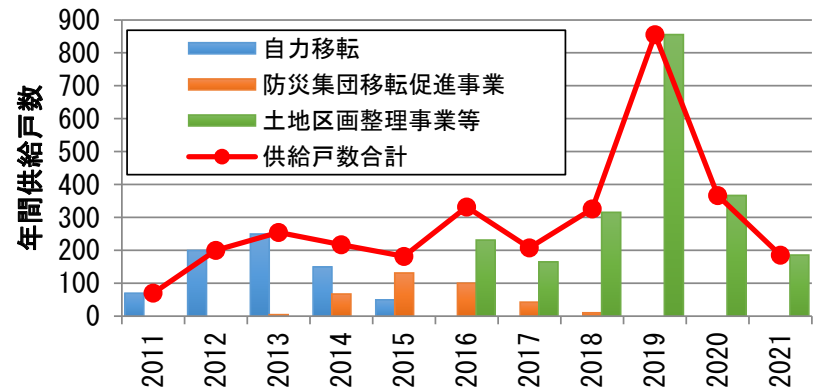

(b) 陸前高田市

図 3 岩手県気仙管内二市の住宅供給戸数予測（2014 年 3 月時点） 
果の一部を図 6 に示寸が、価格に加え間取りへの関心が高く、これ らは以後のモデルプランの作成等に活かされた。

この時期、被災地では地場の事業者や行政は様々な復旧業務が錯 綜し住宅再建支援に注力することは難しい。気仙管内において被災 を免れた住田町に実住宅を建設し住宅再建イメージの具現化につな げる公益的な取組みは、今後の予定が立たない被災世帯の住宅再建 意欲の維持・向上に有効な手段と言える。

これらが実現できたのは、古くから広域ごみ処理等の地域連携が 保たれていた二市一町において、発災直後にスタートした気仙環境 未来都市構想等の一環に位置付けられたことによるところが大きい。 一般的には被災自治体と近接する支援自治体の間で予め協議を行い、 事前復興計画等に位置づけておくほかに、意義・効果に関して住民に 周知・理解を得ておくことが重要であろう。

\section{(2) 住民主体の再建支援活動【図 2 (b)】}

前述（1）の活動と同時期に、沿岸二市では各地区で防災集団移転 協議会が設立され、移転先、造成宅地数などの協議が自治体と被災住 民の間ではじまっていた。しかし、全ての地区が集落一体となった高 台移転に向かうわけではない。表 1 に示寸ように、震災後 3 年経過 時の状況から推計した、「公的造成」と自ら土地を取得して再建寸る

「自力再建」の比は、災害公住を除けば大船渡市 $5: 5$ 、陸前高田市 $7: 3$ であり、長期間の復興が予想されるなか自力再建者が増加傾向にあ った。協議会だけでは、自力再建者は対象から外れ、集落のコミュニ ティからも外れてしまう恐れもある。

これらを避けるため、陸前高田市気仙町要谷・福伏地区においては、 その地区の仮設自治会等が中心となりながら集落単位で被災世帯を 束水、住宅再建に取り組む動き(陸前高田要谷・福伏の住宅再建を考 える会、のちに陸前高田住まいの再建を考える会に発展) がスタート し、筆者らに支援の要請があった。住民等との議論・要望を基に、資 金計画支援のためのファイナンスプランナー、二重ローン対応のた めの弁護士組織（東日本大震災法律援助事業活用）、そして地場住宅 事業者有志で構成する再建住民主体の組織を構築した。要谷・福伏地 区を対象に、住民説明会・相談会を 10 回開催したが、被災住民が抱 えている共通の意向は、資金問題や職・収入、年齢などの理由から低 廉であること、そして和室続き間等の震災前の住様式・規模に強いこ だわりがあることなどであった。住民との打合せを重亦て、建材・住 宅設備機器の共通仕様化等や主要構面を外周壁で確保して形態をコ ンパクト化し、水回り等を除く住空間は建具等の可動間仕切で空間 の融通性を高め、将来的には増築にも耐え得る構法システムを前提 とし、最初の費用負担を抑えて時とともに成長する可能性を有する 「最初は最少住宅（図 7)」というコンセプトが生まれた。

要谷地区防集事業の造成完工の 1 年程前にあたる 2015 年 12 月に、 近傍の高台にこのコンセプトに基づく 2 棟の自力再建住宅が完成し （図 8) 一般公開を行ったが、半日で約 100 名の来場者があり高い関 心があることが確認できた。要谷地区が陸前高田市では最初となる 防集事業による住宅再建が完了した地区となった背景には、住民主 体の活動の存在が少なからず関係していると思われる。この後、市内 各地区の防集協議会や仮設自治会から、住宅セミナーの開催やモデ ルプランの説明会についての問合せが多数あり、本会は市内全域に 活動対象を広げた組織へと拡大した。

住民主体の支援活動は、地区が限られ再建戸数が少量で需要に対

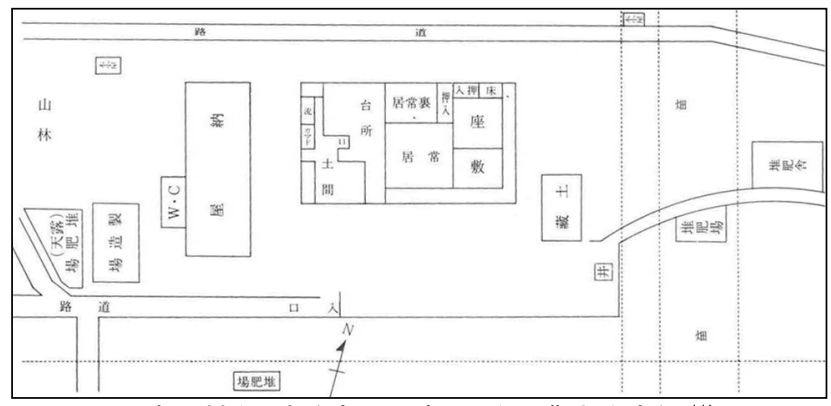

図 4 廣田村 (現陸前高田市広田町) の農家住宅例 ${ }^{1}$

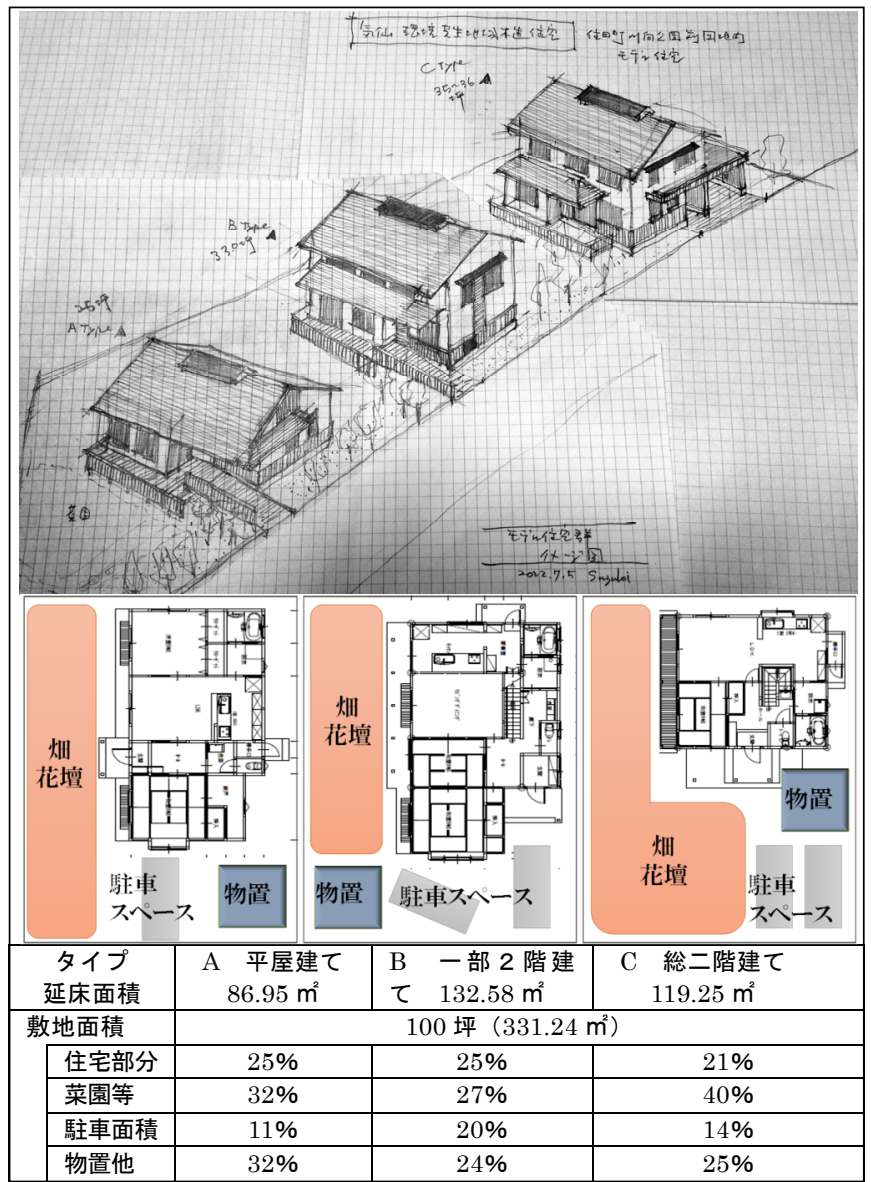

図 5 復興モデル住宅の敷地空間利用率
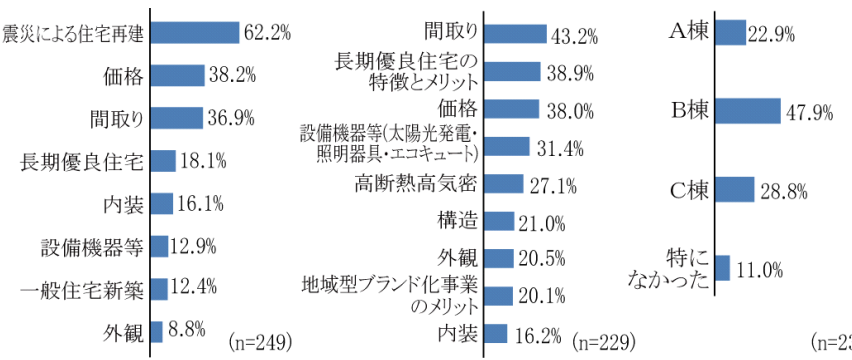

(a) 見学会参加の関心事 (b) モデル住宅で興味のあった事項 (c)住要求に合うモデル 図 6 見学会アンケート結果の一例（複数回答あり）

表 1 陸前高田市·大船渡市の住宅再建比率の推測注5) 注8) : 2014 年 3 月末時点

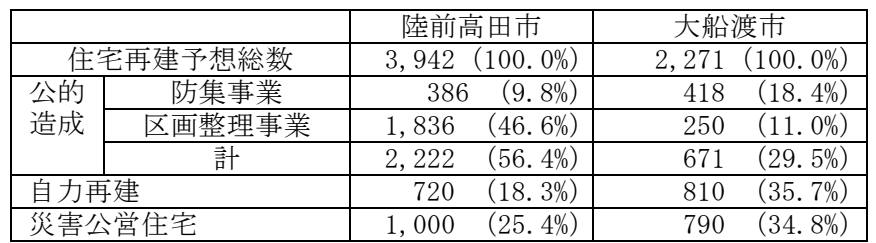


応できるうちは住宅再建意欲を高め加速化も期待できる。しかし、地 区、再建戸数が増えた場合は、専門家、連携する住宅事業者を含めた 体制強化が必要不可欠となる。

（3）住民と地場実務者等が中心となった総合的支援活動【図 2 (C)】 前述した活動を経て、2014 年 4 月から陸前高田市を対象に、(2)で 述べた住民主体の体制と一般社団法人陸前高田市建設業協会会員社 や協賛建材・住宅設備メーカー、市内建築士等の常駐相談員、仮設住 宅連絡会、金融機関等のファイナンシャルプランナーや弁護士など のアドバイザー、筆者らなどからなる「陸前高田市住宅再建推進協議 会」を(一社) 陸前高田市建設業協会内に設置した。この協議会は、 陸前高田市からの補助金を得て運営しており、現在も活動している。

表 2 に設立から昨年度までの主な活動内容を示す。活動は、(1)住 宅再建等に関寸る説明会や相談業務等の公益的支援活動、(2)陸前高 田市内の住宅再建活動之技術力向上研修等、(3)住民意向調查注3) や住 宅再建動向調查注4) などを行い、活動の検証や今後の住宅ニーズと活 動方向を探るための取組みに大別される。市内各地で行う住民説明 会・相談会から得られる要望や、被災世帯を対象に再建ニーズと経年 変化などを把握するため毎年同時期に実施する住民意向調查、さら には実際に再建された住宅属性や建設事業者を把握するための住宅 再建動向調查の結果を基に、被災者への再建支援活動や地場住宅事 業者への技術支援に反映し、変化するニーズに対応した効率的な住 宅再建支援を行うという事業スキームである。

住宅再建の長期化による住要求の経年変化をみるため、図 9〜11に、 2014 年と 2018 年に実施した住宅再建意向調查結果を示す。なお本調 查は住宅再建が未了な仮設住宅居住者を主な対象としているため、 再建の進行に伴い調查母数が減少する。ここでは未再建者の意向の 経年変化を知るため比率で比較することとした。図 9 は戸建住宅の 再建を希望する世帯属性を示したものだが、経年により世帯人員が 全て 60 歳未満の世帯と 60 歳以上単身世帯の割合が増加しており、 再建世帯の大勢は変化している。造成完了を待つ再建者が多くを占 めると考えられるが、属性の変化からは、住宅資金や仕事の見通しの 不安により再建を躊躇する世帯も少なからず残っていると想像され る。図 10 は住要求の経年変化を示したものだが、終始一貫して建設
コストへの関心が最も大きいものの、その割合は減少し、一方でアフ ターメンテナンスや建設後の維持修繥に関心のある層の割合が微増 している。さらに図 11 は協議会活動に求められる役割の変化を示し たものだが、住宅再建が進むにつれて、前述した世帯属性の変化も関 係してローン・資金計画に関する相談等を求める声が大きくなって きていることがわかる。こうした個別的かつプライベート性の高い

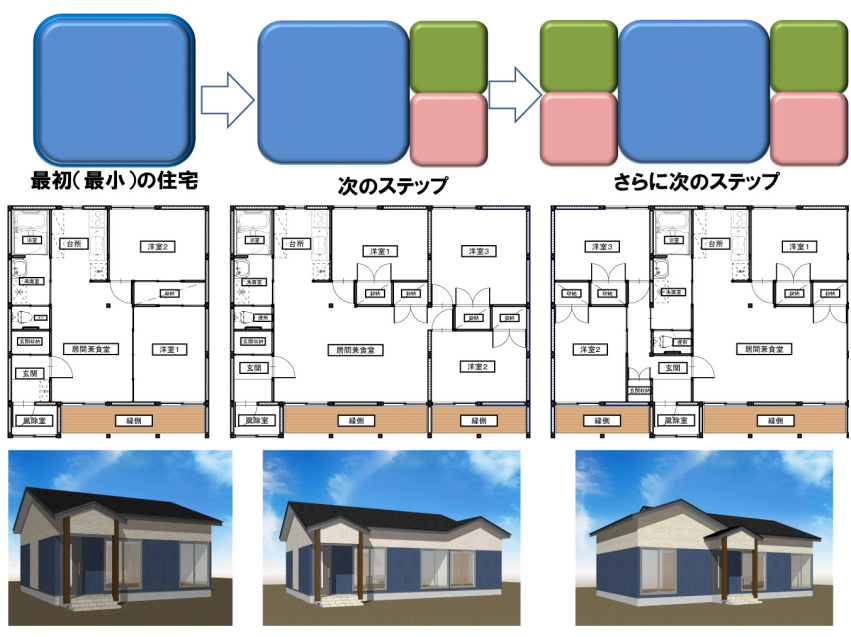

図 7 「最初は最少住宅」コンセプト

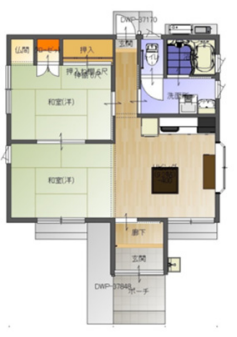

1階平面図
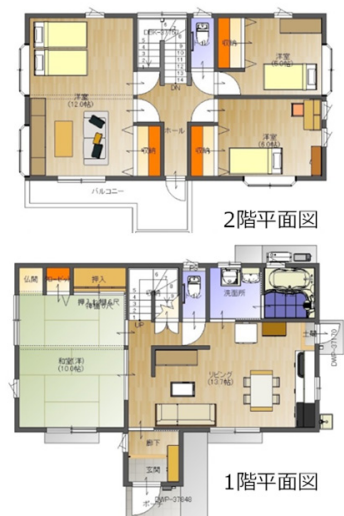

(a) 平屋建てタイプ（約 15 坪）

(b) 2 階建てタイプ(約 35 坪)

図 8 上記コンセプトを基に建設した住宅概要

\section{表 2 協議会の主な活動概要（2014～2019 年度）}

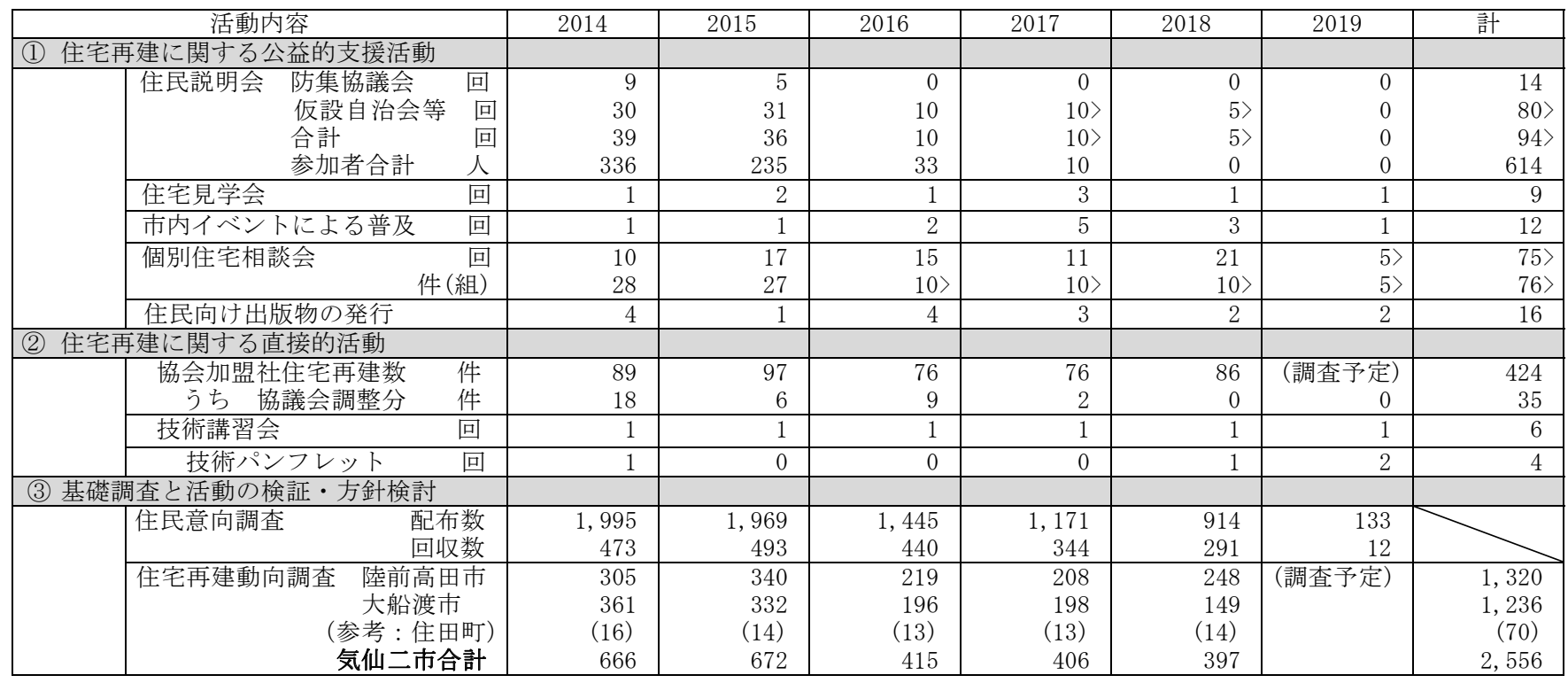


相談に対応し、これまで団体を対象として開催した住宅相談会を減 少させ、金融機関などと連携し個別相談会の比率を高めて対応して きた。

また、図 12 は住宅再建動向調査に基づく陸前高田市内に再建され た個人住宅等の事業者の所在地を示したものである。気仙管内の地 場事業者等（2市 1 町と直営を含む）は、2012 年以降は毎年 97 153 軒の住宅再建を行っており、各年で 45〜 52\%のシェアを確保してい る。総建設戸数が 2015 年の 308 軒に対して 2016 年は 182 軒と大き く減少しているが、減少率が大きいのは気仙以外の岩手県内事業者

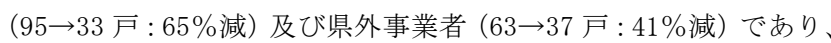
気仙管内事業者等 $(146 \rightarrow 111$ 、24\%減) の減少率は比較的小さい。2018 年には総建設戸数の増加に伴い気仙以外の岩手県内事業者及び県外 事業者の建設数が増加している 2015 年と 2018 年は防集事業及び土 地区画整理事業の造成完了地区が集中した時期であり、これらの事 業者が大規模な需要のある団地に集中して営業活動を行っているこ との現れと推測される。一方、地場の事業者は一時的大量需要への対 応力は乏しいものの、比較的安定して住宅再建を行っていることが わかる。過去の震災では、地域事業者が一時的に発生する大量の住宅 再建に対応するため経営規模を拡大し、住宅再建が収束するなかで 経営悪化・倒産するケースが散見されるが、それらリスクを軽減する ため一時的な経営・生産能力を拡大していないことも生産量が安定 的に推移している一因である。

当初、防集事業及び区画整理により民間宅地造成事業が進み、2015 年度及び 2019 年度ごろの宅地供給のピークに合わせ大量の住宅需要 が発生することを想定しており (図 3(b))、事業者がこれらの需要に 合わせた対応を検討・準備するため、各年末、住宅再建動向調査に基 づく将来予測を行っていた注 5)。図 13 は最大ピークが発生すると考
えていた 2018 年以降の建設戸数予測の変化を示したものだが、2014 〜2017. 3 までの推計では、区画整理の事業計画に基づき住宅供給数 の下方修正に伴い減少傾向とした。2017.12 の推計では、区画整理で 供給される土地の所有者のうち、当該敷地で再建寸る世帯が約 $1 / 3$ で あるという市の調査結果を踏まえ、大幅に下方修正した。2020.3 の 推計は、これまで住宅再建を果たした世帯数、災害公営住宅に入居さ れた世帯数をふまえ、残数を按分する形で推計した。結果として、毎 年の推計で 2020 年に見込まれたピークは徐々に小さくなった。この ことは協議会で早くから共有されたが、すでに住宅建設の減少を実 感する事業者がみられ、仕事の減少に向け維持管理やリフォーム部 門の検討、技術の向上や継承にかかる取り組みなどの対策を急ぐこ ととなった。過去の大規模災害と同様、一時的な住宅建築の大量建設 は、その後の地場建設業の急速な衰退を招き、それが地域経済や雇用 に影響を及ぼすことは避けられない。そのため、住宅再建に終息が見 えてきた陸前高田市においても、地場建設事業者の新たな役割を検 討すべき時期に来ている。

\section{3. 地域住宅再建推進の体制づくりに関する考察}

本報で述べてきた活動の変遷は、予め想定していたものではなく、 復興状況の進行・変化と関係者・機関との議論のなかから生まれたも のである。今後の大規模津波災害に対応した地域住宅再建推進の体 制づくりにおいては、発災後に議論を開始し実現することは困難と 想定されることから、事前の近隣市町村との協力体制、建設業者間の 連携体制について事前復興計画等に位置付けるとともに、対象住民 に対して事前の理解を得ておく必要がある。一連の活動で得られた 知見を基に、以下に復興プロセスに応じた体制の在り方を示す。 ・被災エリアが復旧初期段階においては、被災していない後方支援地

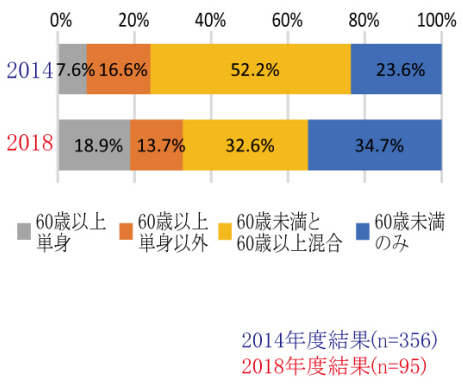

図 9 住宅再建希望世帯の年齢構成注 4$)$

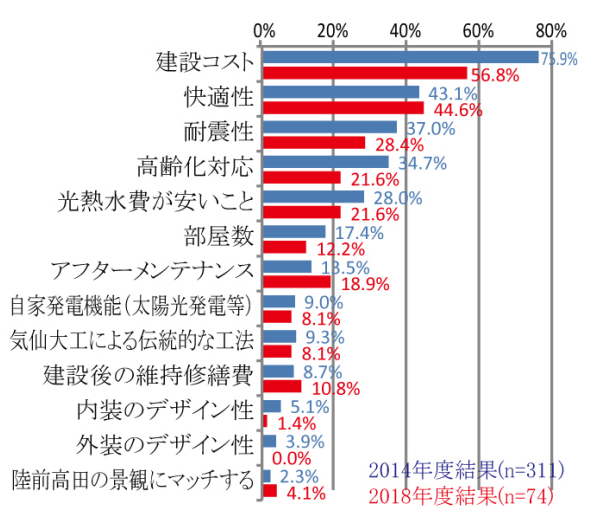

図 10 住宅再建希望世帯の住要求注4)

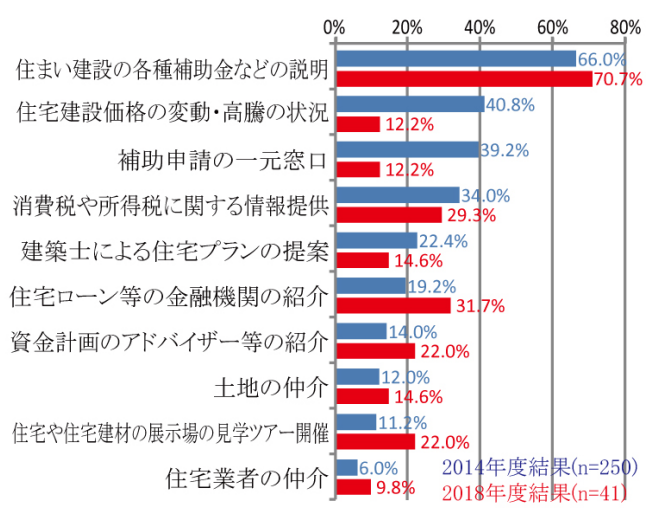

図 11 住宅再建希望世帯が協議会に求める役割注4)

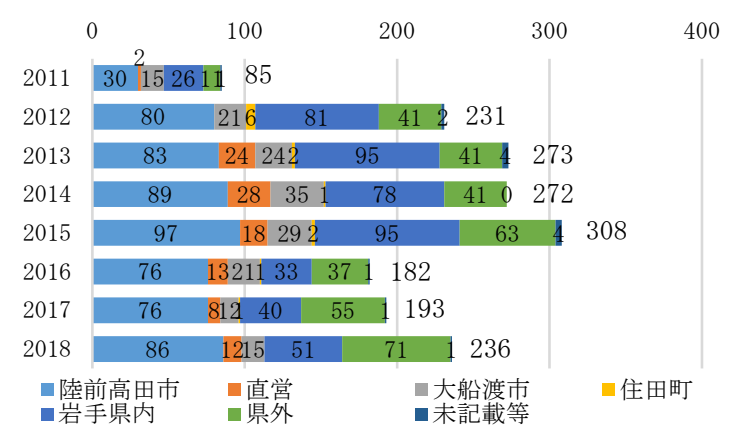

図 12 陸前高田市内の新築住宅数と住宅事業者所在地注 3$)$

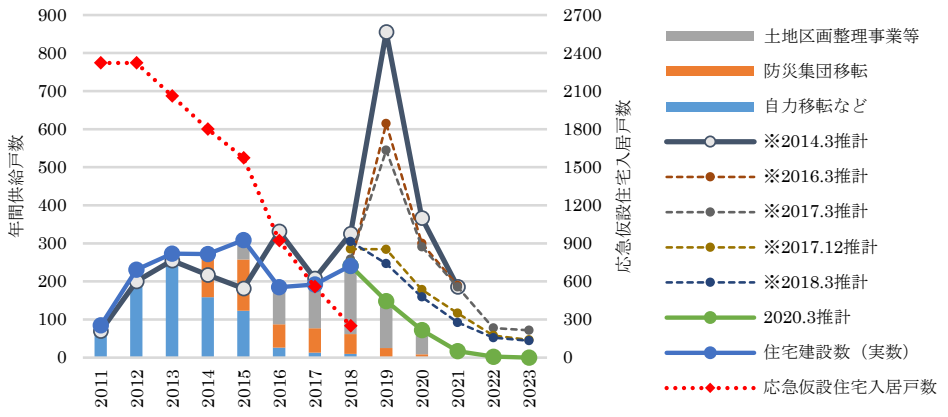

図 13 年度別住宅供給数 (2018 年度末まで実績、2019 年度から推計) 
を拠点として、被災世帯それぞれの住宅・生活再建の相談業務や将 来像を具現化する公益的支援を主とした体制とする。

・地区のコミュニティ崩壊を避けるため、具体の地域での組成期は防 集事業や区画整理事業単位ではなく地区・集落単位の被災者を起 点とし、徐々に地場の実務家やファイナンシャルプランナーなど を含め再建者グループを形成し、各種情報提供、相談会が実施でき る体制とする。

・建設業協会などを中心に住宅再建にかかわる地場事業者をグルー プ化し、様々な住要求に合わせたモデルプランの策定や近隣のプ レカット事業者との連携や建材・住設機器の共通化により安定供 給と建設コストの低廉化システムの検討構築を図る。

・隣接被災地間で被災程度や造成完了時期に差がある場合は、双方の 供給量に応じて生産・労働力などを振り分けるなど、広域的にコン トロールして雇用・生産力の平準・安定化を図る。

・これらの体制構築、適切な変容時期を予察するため、再建前後の被 災世帯に対する意向調查、住宅再建動向を定期的に把握し活動に 反映する。

なお、災害公営住宅等では実現が難しい、なりわい継承と都市経営 の効率化を意識した民間賃貸低層集合住宅などの補完的供給も必要 に応じて検討を行うことが望まれる。また、住宅再建が終息に向かう 段階から、「つくる (住宅再建)」から「つかう（維持管理、賃貸や空 き住戸の再販など)」を主業務とした体制に転換する必要がある。高 齢化が急速に進んでいることから、安心な暮らしのために、社会福祉 協会や近隣医療機関などと連携した体制づくりも次のフェーズとし て求められる。

筆者らが陸前高田市で行ってきた住宅再建推進活動も、発災から 10 年目に入るが、未だ住宅再建の目途がつかない数十世帯の住宅再 建の支援など、残された課題は少なくない。またこれまで復興を支え てきた地場建設事業者のなかには深刻な経営問題に直面しはじめて いるものもいる。それらの課題に対し、引き続き対応策の検討・実践 を続け、今後の体制のあり方提案に結びつけていきたい。

\section{謝辞}

本活動は、岩手県気仙管内の被災住民の方々、建設事業者、自治体、国土交 通省等の方々との多くの議論、意見をもとに展開してきたものである。また、 一連の活動において道総研職員の協㗢なしにはここまで継続し得なかった。 記してこれらの方々に深謝します。

\section{【参考文献】}

1）鈴木大隆 : 季刊まちづくり 42 号特集「地域力と “ぎりすび”を活かした 「住宅再建体制構築」への取組み一岩手県気仙の住まい」, 2014 年 4 月。

2）鈴木大隆・石井旭 : 陸前高田における地域居住へむけた取り組みその 1 12 の一連の報告（2015～2020），日本建築学会大会学術講演梗概集.

3) ISHII A., et al. : RESIDENTIAL LAND SUPPLY METHODS TO DEVELOP A HOUSING RECONSTRUCTION SCENARIO IN A LARGE TSUNAMI-DEVASTATED AREA, J. Archit. Plann., AIJ, Vol. 83 No. 749, 1273-1283, Jul. 2018. 石井旭・鈴木大隆・瀬戸口剛 : 住宅復興シナリオ構築に向けた津波被災地 の宅地供給手法, 日本都市計画学会計画系論文集, 第 83 巻, 第 749 号, 273-1283，2018 年 7 月.

4) MASUO K., et al. : A COMPARATIVE STUDY OF THE "SELF-RECONSTRUCTION HOUSING SUPPORT" FROM THE VIEWPOINT OF THE SUPPLY OF REGIONAL HOUSING IN RECONSTICTION MACHIZUKURI, J. Archit. Plann., AIJ, Vol.82, No.735, 1187-1197, May 2017.

益尾孝祐，後藤治，三井所清典 : 復興まちづくりにおける地域型住宅の供 給戸数から見た自力再建住宅支援の生産システムに関する比較研究, 日本 建築学会計画系論文集, 第 82 巻, 第 735 号, pp1187-1197, 2017 年 5 月.

5）小花璃美，山本俊哉ら:集団移転協議会による津波被災低地の利用計画の 協議：陸前高田市における住宅再建に関する研究 (9), 2014 年度日本建築
学会大会学術講演会・建築デザイン発表会, pp331-332, 2014.09

6）福岡市：玄界島震災復興記録誌，2011.3.

7) OYANAGI, T. \& KAWAKAMI, M. : STUDY ON UTILIZATION OF SUPPORT SYSTEM FOR RECONSTRUCTING OR REPAIRING OF DAMAGED HOUSES BY NOTO PENINSULA EARTHQUAKE, J.Archit. Plann., AIJ, Vol. 76, No.662, 789-797, Apr. 2011.

小柳健，川上光彦：能登半島地震被災地の住宅再建における公的支援事業 の活用実態と課題, 日本建築学会計画系論文集, 第 76 巻, 第 662 号, pp789-797, 2011 年 4 月.

8) 岩手県.宮城県·福島県地域型復興住宅推進協議会, 住宅金融支援機構東北 支店: 地域型復興住宅パンフレット, 2012 年 3 月初版, 2013 年 2 月第 2 版.

9) Takeuchi, K., et al. : CLASSIFICATION OF THE ALLIANCE OF LOCAL CONSTRUCTOR FOR THE WOODEN PUBLIC HOUSING CONSTRUCTION PROJECTS AFTER THE GREAT EAST JAPAN EARTHQUAKE, AIJ J. Technol. Des. Vol.23, No. 53, 215-218, Feb. 2017.

竹内賢吾ら : 東日本大震災の木造災害公営住宅事業における生産者協議会 の類型化，日本建築学会技術報告集，第 23 巻，第 53 号，215-218， 2017 年 2 月.

10）内閣府（防災担当）：被災者の住まいの確保に関する取り組み事例集, 2019 年 3 月。

11）廣田尋常高等小學校、廣田村實業補習學校編 : 廣田村郷土教育資料第三 輯 三、住居 附図二 農家代表 字山田 村上善三郎宅図面, 1981 年.

\section{【注】}

注 1）H21 時点で大船渡市、陸前高田市の建設業関連 392 事業所はすべて 300 人以下の中小企業者で、うち $93.6 \%$ にある 367 事業所は 20 人未満の小 規模企業者 : H21 経済センサス基礎調査

注 2) 北海道南西沖地震、兵庫県南部地震、新潟県中越地震は新設住宅着工 数、東日本大震災における陸前高田市に関しては 2014 年 3 月時点の災害公 営住宅及び民間宅地供給計画数の合計值とし、最大ピークを 100 とした供 給数割合を示している.

注 3) (一社) 陸前高田市建設業協会住宅再建推進協議会が陸前高田市で被災 した応急仮設住宅居住世帯に対し 2014 年〜2018 年に実施した「住まいの再 建等に関する意向調査」結果より作成. 調査内容は 5 分類、計約 35 問から なり、ほぼ同じ内容の調査を毎年秋に実施することで経年変化を把握する ことが可能。

注 4) 建築基準法第 93 条の 2 に規定される建築計画概要書の閲覧制度を活用 し人手したデータから構筑.

注 5）復興庁「住まいの復興工程表」（2014 年 3 月末現在）、陸前高田市「高 田地区・今泉地区被苂市街地復興土地区画整理事業等事業計画（案）の説 明会資料」(2013 年 11 月) を参考に年度別民間宅地供給計画数を明らかに し、造成完了年次の翌年 1 年次 $0.6 、 2$ 年次 $0.25 、 3$ 年次 0.15 で丸 3 年で 全竣工寸るとして推計.

注 6) 岩手県建築動態調査によれば、2010 年度の気仙管内（大船渡市、陸前 高田市、住田町）の新設住宅着工戸数は合計 178 戸である.

注 7) 平成 23 年 (2011 年) 東北地方太平洋沖地震（東日本大震災）について （第 159 報），2019 年 3 月, 消防庁による大船渡市、陸前高田市の住宅全 壊棟数.

注 8) 当時の推計では、住まいの復興工程表に自力再建の増加に伴う区画整理 事業及び災害公営住宅の減少等の計画変更が反映されていないため、再建 総数が被災戸数を上回っている.

[2020 年 10 月 7 日原稿受理 2020 年 12 月 11 日採用決定］ 